ISSN 0103-5150

Fisioter. Mov., Curitiba, v. 29, n. 3, p. 477-485, Jul./Set. 2016

Licenciado sob uma Licença Creative Commons

DOI: http://dx.doi.org.10.1590/1980-5918.029.003.A005

\title{
Relationship between health behaviors and self-reported diseases by public employees
}

\author{
Relação entre comportamentos em saúde e \\ doenças autorreferidas por servidores
}

\author{
Janaina Maria Setto $^{[a]}$, Palmira de Fátima Bonolo ${ }^{[b]}$, Sylvia do Carmo Castro Franceschini ${ }^{[c] *}$ \\ [a] Centro de Instrução Almirante Braz de Aguiar (CIABA)/Brazilian Naval Service, Belém, PA, Brazil \\ [b] Universidade Federal de Minas Gerais (UFMG), Belo Horizonte, MG, Brazil \\ [c] Universidade Federal de Viçosa (UFV), Viçosa, MG, Brazil
}

\begin{abstract}
Introduction: Life habits such as physical activity, leisure, eating habits, stress, smoking, and alcohol consumption can directly affect individuals' health. Objective: This study aimed to investigate the relationship between health behaviors and diseases self-reported by employees of a federal public university in southeastern Brazil. Methods: This cross-sectional study included 815 employees, of whom 347 were teachers and 468 were technical-administrative staff, aged between 20 and 65 years old. Data from this study were collected from a secondary database, from the Health Questionnaire (self-reported health conditions by teachers and technical-administrative employees), and from the institution's Vice Dean of Community Affairs. Among the variables assessed, the relationship between eating habits, physical activity, smoking, alcohol consumption, and self-reported illnesses (chronic diseases and infectious and parasitic diseases diagnosed by a doctor within the last 12 months) was analyzed. Results: The mean prevalence of these diseases among teachers and technical-administrative staff was 3.1 and 2.9, respectively. This study showed a statistically significant association between unhealthy diet and cerebrovascular accidents; between irregular performance of physical
\end{abstract}

\footnotetext{
*JMS: MS, e-mail: jsetto@gmail.com

PFB: PhD, e-mail: pfbonolo@gmail.com

SCCF: PhD, e-mail: sylvia@ufv.br
} 
activity/sedentary lifestyle and endocrine/nutritional/metabolic and digestive diseases; between overweight and cardiovascular diseases, endocrine/nutritional/metabolic diseases, diabetes mellitus, and hypertension; and between smoking and musculoskeletal diseases. Conclusion: We suggest the adoption of preventative measures and the control of risk behaviors among these employees.

Keywords: Occupational Health. Risk Behavior. Chronic Disease. Disease Prevention.

\section{Resumo}

Introdução: Os hábitos de vida como a prática de atividade física, o lazer, os hábitos alimentares, o estresse, o tabagismo e etilismo podem implicar diretamente nas condições de saúde do indivíduo. Objetivo: Este trabalho teve como objetivo verificar a relação entre comportamentos em saúde e as doenças autorreferidas por servidores de uma universidade pública federal da região sudeste. Métodos: Participaram do estudo 815 servidores, sendo 347 docentes e 468 técnico-administrativos, com idade de 20 a 65 anos. Trata-se de um estudo transversal. Os dados deste estudo foram coletados de um banco de dados secundário, provenientes do Questionário de Saúde (condições de saúde autorreferidas por docentes e técnico-administrativos), da PróReitoria de Assuntos Comunitários da Instituição. Dentre as variáveis avaliadas, foi verificada a relação entre o hábito alimentar, a prática de atividade física, o tabagismo e o consumo de bebida alcoólica com as doenças autorreferidas (doenças crônicas não transmissíveis e doenças infecto-parasitárias, diagnosticadas pelo médico nos últimos 12 meses). Resultados: A média de doenças entre esses docentes e técnico-administrativos da pesquisa foi de 3,1 e 2,9, respectivamente. Destacou-se nesse estudo a associação estatisticamente significante da alimentação não saudável com o acidente vascular encefálico; a atividade física irregular/sedentarismo com as doenças endócrinas/nutricionais/metabólicas e do aparelho digestivo; o excesso de peso com as doenças cardiovasculares, doenças endócrinas/nutricionais/metabólicas, diabetes mellitus e hipertensão arterial sistêmica; e o tabagismo com as doenças osteomusculares. Conclusão: Sugere-se a adoção de medidas de prevenção e controle dos comportamentos de risco entre esses servidores.

Palavras-chave: Saúde do Trabalhador. Comportamento de Risco. Doença Crônica. Prevenção de Doenças.

\section{Introduction}

Chronic non-communicable diseases (CNCD) are the main cause of morbidity and mortality in the world (1). In 2008, these diseases accounted for $63 \%$ of all deaths worldwide (1). In Brazil, this rate reached $72.4 \%$ in 2009 (2).

Lifestyle habits may have a direct influence on people's health conditions. An inadequate diet, a sedentary lifestyle, alcohol consumption, and smoking, as well as stress, may favor the development of morbidities, especially CNCDs (3).

Poor eating habits are a risk factor for obesity and other CNCDs, such as heart diseases, diabetes, and certain cancers (4). The advent of nutritional transition, characterized by an increase in the consumption of high caloric foods and a decrease in the consumption of fiber-rich foods, occurred simultaneously with an epidemiological transition process, which is characterized by an increase in cases of CNCDs and a decrease in cases of infectious diseases (5).
Overweight has increased among the Brazilian population since the 1970s. According to the Family Budget Survey (POF, as per its acronym in Portuguese), the prevalence of overweight and obesity among people aged 20 or over was $49 \%$ and $14.8 \%$ respectively. In addition, low consumption of fiber-rich foods, such as fruits and vegetables, was observed together with high consumption of high-fat foods, sugar, and salt (6).

Studies have pointed out that, as of 2008, a sedentary lifestyle accounted for $6 \%$ of heart diseases, $7 \%$ of type 2 diabetes, $10 \%$ of breast and colon cancer, and $9 \%$ of premature deaths. That is, more than 5.3 million out of the 57 million deaths that occurred globally $(7,8)$. According to the National Households Sample Survey (PNAD, as per its acronym in Portuguese), in that same year, only $10.2 \%$ of Brazilians aged 14 or over performed a physical activity (9).

Among licit drugs, tobacco is the main cause of several diseases, including lung cancer, 
cardiovascular diseases, and chronic obstructive pulmonary disease (10). In 2008, the World Health Organization (WHO) reported that tobacco was the cause of death among one-third to one-half of smokers, with their lives being shortened by nearly 15 years (11). In that same year, the PNAD reported that $17.5 \%$ of the Brazilian population aged 15 or over used some kind of tobacco, which accounts for nearly 25 million people (9). A survey carried out in the state of Minas Gerais in 2010 indicated that $14.7 \%$ of adults were smokers (12).

However, the most consumed drug in the world is alcohol, both for social drinking and abusive use (13). WHO estimates that there are two billion alcohol users in the world (13). The harmful use of alcohol is one of the risk factors with great impact on morbidity/mortality and disabilities in the world and it may be related to 3.3 million deaths every year. Therefore, nearly $6 \%$ of all deaths are totally or partly attributed to alcohol. The amount consumed and the consumption pattern affect the risk of harm over time. Occasional heavy use, which corresponds to 60 grams or more (nearly five doses* or more) of pure alcohol on one single occasion at least once in the last month, is related to several acute problems, such as accidents and violence. In 2010, this pattern was observed in $16 \%$ of consumers around the world and in $22 \%$ in Brazil (14).

In view of the lack of information about the health of public employees of a federal public university in the southeastern region of Brazil, this study aimed to assess the relationship between health behaviors and self-reported diseases by these public employees. These findings are expected to contribute to a health policy for workers based on prevention and control of risk behaviors and the prevention of diseases.

\section{Methods}

This study has a cross-sectional design and was carried out with professors and technical-administrative employees of a federal public university of the Brazilian southeastern region.

The institution employs 1,184 professors and 2,316 technical-administrative employees, totaling 3,500 active employees distributed over three campuses.

The sample power was calculated considering an expected event frequency of $18 \%$, which corresponded to the percentage of mental and behavioral disorders reported by the WHO (10), with an acceptable variability margin of $10 \%$ and confidence level of $99.99 \%$, indicating the need for a minimum sample of 317 employees.

Data were collected from a secondary database that is, from a health questionnaire (self-reported health conditions by professors and technical-administrative staff) issued by the institution's Vice Dean of Community Affairs. This questionnaire was made available on the institution's website between May and June 2012, which made it a convenience sample. The invitation to fill in the questionnaire was sent by the department via e-mail to all active employees of the institution.

Thus, all employees who answered the health questionnaire took part in the survey, that is, 815 employees (23.3\%), of whom 347 were professors and 468 were technical-administrative staff, which corresponded to $29.3 \%$ and $20.2 \%$ respectively.

Among the variables assessed, the relationship between eating habits, physical activity, smoking, alcohol consumption, and self-reported diseases (CNCDs and infectious and parasitic diseases diagnosed by a physician within the last 12 months) was observed.

Food consumption was classified as healthy, moderately healthy, and unhealthy, and was structured according to the guidelines of the Food Guide for the Brazilian Population (4). These guidelines recommend the daily consumption of three servings of fruit, three servings of vegetables and greens, one serving of legumes (beans), three servings of milk and dairy products, one serving of meat, fish or eggs, one serving of fats and oils (preferably vegetable oils, olive oil, and trans fatty acid-free margarines), six servings of rice, bread, pasta, cereals, or roots. To analyze participants' consumption, an instrument composed of 11 items was created, in which 10 were scored from 0 to 2 and one was scored with 0 or 2 . In the assessment of results, diet was scored as follows: 17 to 22 points (healthy), 10 to 16 points (moderately healthy), and 0 to 9 points (unhealthy).

In order to determine the degree of physical activity, the International Physical Activity Questionnaire (IPAQ) version 8 was applied and validated for a sample of the Brazilian population (15). The version used was the shorter one, which contained questions about frequency and duration of moderate and intense physical activities, as well as walking, performed in the previous week. To the analysis of data on the degree 
of physical activity, we adopted the consensus, found in 2002 between the Study Center of the Laboratory of Physical Fitness of São Caetano do Sul (CELAFISCS) and the Centers for Disease Control (CDC) in Atlanta, in which the criteria of frequency and duration were assessed, categorizing individuals as very active, active, moderately active, and sedentary (15).

The Body Mass Index (BMI) was calculated with weight and height measures, following the formula BMI = weight $(\mathrm{kg}) /$ height $^{2}(\mathrm{~m})$. The BMI cut-off points adopted to assess the nutritional status of adults were: low weight $\left(<18.5 \mathrm{~kg} / \mathrm{m}^{2}\right)$; eutrophic $(18.5$ $\left.24.9 \mathrm{~kg} / \mathrm{m}^{2}\right)$; overweight $\left(25.0-29.9 \mathrm{~kg} / \mathrm{m}^{2}\right)$; and obesity ( $\geq 30.0 \mathrm{~kg} / \mathrm{m}^{2}$ ) (16).

To assess the degree of nicotine dependence, the Fagerstrom Test for Nicotine Dependence (FTND) was used, with a version validated for Brazil by Carmo and Pueyo (17). This instrument is composed of six questions in which two are scored between 0 and 3 and the others are scored between 0 and 1 . In the analysis of results, the degree of dependence was classified according to the scores 0 to 4 (slight), 5 to 7 (moderate), and 8 to 10 (heavy).

To determine the alcohol consumption pattern, the Alcohol Use Disorder Identification Test (AUDIT) was applied. This instrument detects problems related to alcohol consumption over the last 12 months, and it is composed of 10 items, each one ranging from 0 to 4 points, with a possible score between 0 and 40 . In the analysis of AUDIT results, a score between 0 to 7 indicates Zone I (low risk); scores between 8 and 15 indicate Zone II (medium risk); scores between 16 and 19 indicate Zone III (high risk or harmful use); and between 20 and 40 indicate Zone IV (alcohol dependence is very likely) (18).

The database was exported to a Microsoft Excel sheet and analyzed by SPSS Statistics version 17.0. A descriptive statistical analysis was performed, in which the simple and relative frequencies of category variables were assessed. These frequencies were analyzed by means of Pearson's chi-square test $\left(\mathrm{X}^{2}\right)$ and prevalence ratio (PR) and its respective confidence intervals (CI) of $95 \%$ were adopted as a magnitude measurement. For rejection of the null hypothesis, a significance level of $(\alpha)<0.05$ or $5 \%$ was adopted.

The study was approved by the Research Ethics Committee of the Universidade Federal de Ouro Preto under number 073/2012 (CAAE: 00676712.9.0000.5150). Because of the use of a secondary source of an existing database, the Institutional Authorization Term and the Declaration of Responsible Use of Data were used, as recommended by Resolution 196/96 of the National Health Council.

\section{Results}

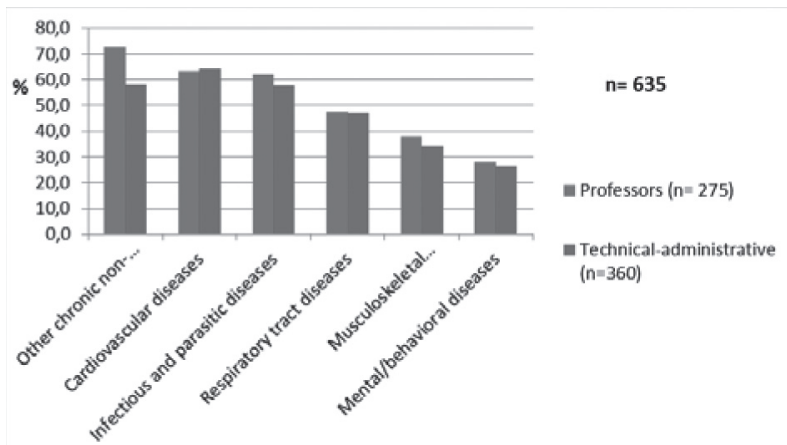

Figure 1 - Percentage of self-reported diseases* by professors and technical-administrative employees of a public university of the southeastern region of Brazil, 2012.

Note: Other chronic non-communicable diseases: voice disorders; diseases of the eye and surrounding structures; endocrine, nutritional and metabolic diseases; thyroid diseases; ear/mastoid region diseases; blood diseases, diseases of the hematopoietic organs, and immune disorders; diabetes mellitus; neoplasias. Cardiovascular diseases: hypercholesterolemia; high blood pressure; circulatory system diseases; nervous system diseases. Infectious and parasitic diseases: Dengue fever; viral hepatitis; digestive system diseases; genitourinary system diseases; skin/tissue/subcutaneous diseases; sexually transmitted diseases. Respiratory tract diseases. Musculoskeletal system/connective tissue diseases. Mental/behavioral diseases: Burnout syndrome; anxiety; depression; stress; cognitive disorder; personality disorder; obsessive-compulsive disorder; posttraumatic stress; bipolar disorder; schizophrenia and others. * Selfreported diseases with a medical diagnosis within the last 12 months.

Figure 1 presents the main groups of diseases that were self-reported by the participants. Among them, 275 professors (79.3\%) and 360 technicaladministrative employees (76.9\%), totaling $635 \mathrm{em}$ ployees $(77.9 \%)$, were diagnosed with at least one disease over the last 12 months. The average number of diseases among these professors and technicaladministrative employees was 3.1 and 2.9 respectively. Among professors, the percentages of CNCDs (72.7\%), infectious and parasitic diseases (62.2\%), musculoskeletal and connective tissue diseases (37.8\%), and mental and behavioral disorders (28\%) 
were greater than among technical-administrative employees, whose percentages were $58.1 \%, 57.5 \%$, $34.2 \%$, and $26.7 \%$, respectively.

Healthy and moderately healthy diets were found for 791 participants in this study (97.1\%), whereas unhealthy diet was found for 24 individuals $(2.9 \%)$. A statistically significant association was observed between diet and cerebrovascular accident (CVA), in which the prevalence of this event was 32.95 times higher among employees who had an unhealthy diet $(4.2 \%)$ than others $(0.1 \%)(\mathrm{p}<0.01$; IC95\%: 2.12 - 511.39). Unhealthy diet did not have any relationship with the other diseases.

As for physical activity, the majority of employees were classified as irregularly active/sedentary $(62.7 \%)$, whereas 304 were active/very active (37.3\%). An association was found between physical activity classified as irregularly active/sedentary and endocrine/nutritional/metabolic diseases (except for diabetes mellitus and thyroid disorders) and diseases of the digestive system. Among irregularly active/sedentary employees (9\%), the prevalence of endocrine/nutritional/metabolic diseases (except diabetes mellitus and thyroid disorders) was 1.95 higher than among active/very active employees (4.6\%) ( $p=0.02$; IC95\%: 1.09 - 3.49). As for irregularly active/sedentary employees (23.1\%), the prevalence of diseases of the digestive system was 1.35 times greater than among the others $(17.1 \%)$ ( $p=0.04 ;$ IC95\%: 1.01 - 1.81).

Regarding weight, 406 employees had a normal/ low weight (50.2\%), whereas 406 were overweight (49.8\%). There was a statistically significant relationship between overweight and cardiovascular diseases, endocrine/nutritional/metabolic diseases, diabetes mellitus, and systemic high blood pressure. Among overweight employees (45.5\%), the prevalence of cardiovascular diseases was 1.56 times higher than among normal/low weight individuals $(29.1 \%)$ (p $<0.01$; IC95\%: 1.29 - 1.88). The prevalence of endocrine/nutritional/metabolic diseases (except thyroid disorders and diabetes mellitus) was 3.02 times higher among overweight employees (11.1\%) than among others (3.7\%) ( $\mathrm{p}<0.01$; IC95\%: 1.71 - 5.33) (Table 1).

Table 1 - Prevalence and prevalence ratio (PR) of self-reported endocrine/nutritional/metabolic diseases and diabetes mellitus* according to diet, physical activity, nutritional status, smoking, and alcohol consumption, Brazil, 2012

\begin{tabular}{|c|c|c|c|c|c|c|c|}
\hline \multirow[b]{2}{*}{ Variables } & \multirow[b]{2}{*}{$n^{*}$} & \multicolumn{3}{|c|}{ Endocrine/nutritional/metabolic diseases } & \multicolumn{3}{|c|}{ Diabetes mellitus } \\
\hline & & $\begin{array}{l}\text { Prevalence } \\
\text { (\%) }\end{array}$ & $\mathrm{p}$ value ${ }^{\star *}$ & PR (Cl 95\%) & $\begin{array}{c}\text { Prevalence } \\
\text { (\%) }\end{array}$ & $\begin{array}{c}\mathbf{p} \\
\text { value }^{\star *}\end{array}$ & PR (Cl 95\%) \\
\hline \multicolumn{8}{|l|}{ Diet } \\
\hline Unhealthy & 24 & 8.3 & 0.85 & $1.13(0.29-4.38)$ & 4.2 & 0.61 & $1.64(0.23-11.78)$ \\
\hline Healthy/moderately healthy & 791 & 7.3 & & & 2.5 & & \\
\hline \multicolumn{8}{|l|}{ Physical activity } \\
\hline $\begin{array}{l}\text { Irregularly active/sedentary } \\
\text { lifestyle }\end{array}$ & 511 & 9.0 & $0.02 * \star \star$ & $1.95(1.09-3.49)$ & 2.9 & 0.40 & $1.48(0.58-3.79)$ \\
\hline Active/very active & 304 & 4.6 & & & 2.0 & & \\
\hline \multicolumn{8}{|l|}{ Nutritional status } \\
\hline Overweight & 406 & 11.1 & $<0.01 * * *$ & $3.02(1.71-5.33)$ & 4.4 & $<0.01 * * *$ & $6.04(1.79-20.36)$ \\
\hline Normal/low weight & 409 & 3.7 & & & 0.7 & & \\
\hline \multicolumn{8}{|l|}{ Smoking } \\
\hline Yes & 71 & 4.2 & 0.28 & $0.55(0.17-1.71)$ & 2.8 & 0.89 & $1.10(0.26-4.64)$ \\
\hline No & 744 & 7.7 & & & 2.6 & & \\
\hline \multicolumn{8}{|l|}{ Alcohol consumption } \\
\hline Yes & 595 & 6.9 & 0.39 & $0.79(0.47-1.34)$ & 2.2 & 0.24 & $0.60(0.25-1.43)$ \\
\hline No & 220 & 8.6 & & & 3.6 & & \\
\hline
\end{tabular}

Note: *Diseases with a medical diagnosis within the last 12 months. 
Considering the relevance of diabetes mellitus and high blood pressure for the health of the general public, prevalence of these diseases was analyzed separately. Among overweight employees (4.4\%), the prevalence of diabetes mellitus was 6.04 times higher than among normal/low weight individuals $(0.7 \%)$ (p
$<0.01$; IC95\%: 1.79 - 20.36). This was also the case for high blood pressure, for which the prevalence was 2.72 times higher among overweight employees $(22.7 \%)$ than among normal/low weight individuals (8.3\%) ( $p<0.01$; IC95\%: 1.88 - 3.94) (Table 2).

Table 2 - Prevalence and prevalence ratio (PR) of self-reported cardiovascular diseases and systemic high blood pressure* according to diet, physical activity, nutritional status, smoking, and alcohol consumption, Brazil, 2012

\begin{tabular}{|c|c|c|c|c|c|c|c|}
\hline \multirow[b]{2}{*}{ Variables } & \multirow[b]{2}{*}{$n^{*}$} & \multicolumn{3}{|c|}{ Cardiovascular diseases } & \multicolumn{3}{|c|}{ Systemic high blood pressure } \\
\hline & & $\begin{array}{l}\text { Prevalence } \\
\text { (\%) }\end{array}$ & p value $* \star$ & PR (Cl 95\%) & $\begin{array}{c}\text { Prevalence } \\
\text { (\%) }\end{array}$ & p value $* *$ & PR (Cl 95\%) \\
\hline \multicolumn{8}{|l|}{ Diet } \\
\hline Unhealthy & 24 & 37.5 & 0.99 & $1.00(0.59-1.69)$ & 16.7 & 0.86 & $1.08(0.43-2.68)$ \\
\hline Healthy/moderately healthy & 791 & 37.4 & & & 15.4 & & \\
\hline \multicolumn{8}{|l|}{ Physical activity } \\
\hline $\begin{array}{l}\text { Irregularly active/sedentary } \\
\text { lifestyle }\end{array}$ & 511 & 37.8 & 0.79 & $1.02(0.85-1.23)$ & 15.1 & 0.68 & $0.93(0.67-1.29)$ \\
\hline Active/very active & 304 & 36.8 & & & 16.1 & & \\
\hline \multicolumn{8}{|l|}{ Nutritional status } \\
\hline Overweight & 406 & 44.8 & $<0.01 * \star \star$ & $1.49(1.24-1.79)$ & 22.7 & $<0.01^{\star * \star}$ & $2.72(1.88-3.94)$ \\
\hline Normal/low weight & 409 & 30.1 & & & 8.3 & & \\
\hline \multicolumn{8}{|l|}{ Smoking } \\
\hline Yes & 71 & 42.3 & 0.37 & $1.14(0.85-1.52)$ & 19.7 & 0.29 & $1.31(0.79-2.15)$ \\
\hline No & 744 & 37.0 & & & 15.1 & & \\
\hline \multicolumn{8}{|l|}{ Alcohol consumption } \\
\hline Yes & 595 & 37.5 & 0.95 & $1.00(0.82-1.22)$ & 16.0 & 0.51 & $1.13(0.77-1.64)$ \\
\hline No & 220 & 37.3 & & & 14.1 & & \\
\hline
\end{tabular}

Note: Prevalence ratio (PR), Confidence interval (Cl); *Number of individuals in the non-weighted sample; ${ }^{* \star} \mathrm{p}$ value in $\mathrm{X}^{2}$ test; ${ }^{* \star \star} \mathrm{p}<$ 0.05 ; *Diseases with a medical diagnosis in the last 12 months.

The use of tobacco was self-reported by $71 \mathrm{em}-$ ployees $(8.7 \%)$ whereas the other 744 employees were non-smokers $(91.3 \%)$. A statistically significant relationship was found between smoking and musculoskeletal diseases, in which the prevalence of these diseases among smokers (40.8\%) was 1.53 times higher than among non-smokers $(26.6 \%)$ (p $=0.01$; IC: 1.13 - 2.08). Smoking did not have any statistical association with other diseases.

The consumption of alcohol was self-reported by 595 employees (73\%), whereas 220 employees reported that they did not consume alcoholic beverages
(27\%). Among those who consumed alcoholic beverages, $75.3 \%$ had their consumption classified as lowrisk. Alcohol consumption did not have a statistical association with any disease.

\section{Discussion}

The prevalence of CVA was greater among employees who had an unhealthy diet. Unhealthy eating may result in nutritional disorders, making individuals more susceptible to infectious diseases and CNCDs 
(4). According to information from the WHO, the insufficient consumption of fruit, vegetables, and greens (daily consumption below 400g or approximately five servings per person) accounts for 2.7 million deaths, $31 \%$ of ischemic heart diseases, $19 \%$ of gastrointestinal cancers, and $11 \%$ of cerebrovascular diseases that occur every year throughout the world $(19,20)$. VIGITEL 2009, a telephone survey for the surveillance of risk factors and chronic diseases, found that only $30.4 \%$ of the adult population consumes these foods regularly, which indicates that only $18.9 \%$ of this population achieved the levels recommended by the WHO (21).

Employees classified as irregularly active/sedentary (9\%) had a greater prevalence of endocrine/ nutritional/metabolic diseases (except diabetes mellitus and thyroid disturbs) than the others (4.6\%). Having a physically active life offers several benefits to health, such as a decrease in body fat, improved cardiovascular, skeletal, and muscular health, and a decrease in anxiety and depression (5).

Regarding overweight, the results found among these employees $(49.8 \%)$ were similar to those of a survey carried out in 2009 with professors (51\%) in this institution (22).

Overweight employees had a greater prevalence of cardiovascular diseases, endocrine/nutritional/ metabolic diseases (excluding thyroid disorders and diabetes mellitus), diabetes mellitus, and systemic high blood pressure. In 2009, professors in this institution had prevalences of high blood pressure of $16.5 \%$ and $1.38 \%$ for diabetes mellitus (22). Obesity is a multifactorial chronic disease characterized by an excess of body fat and it is an important risk factor for various CNCDs (high blood pressure, dyslipidemia, hyperinsulinemia, impaired glucose tolerance) (23). It is worth highlighting that obesity results in an increase in cases of diabetes mellitus, which in turn increases the risk of coronary diseases among this population (24).

Among the participants in this study, it was seen that the irregular performance of physical activity or a sedentary lifestyle and overweight were associated with endocrine/nutritional/metabolic diseases.

The prevalence of musculoskeletal diseases was greater among employees who smoke. Smoking is a risk factor for fractures, which can occur as a result of nicotine toxicity in the bone, resulting in peripheral vasoconstriction, tissue ischemia, and a decrease in oxygen tension $(25,26)$. Smoking is also an important risk factor for morbidity/mortality, because it is associated with different types of cancer, especially lung cancer, pulmonary diseases, systemic high blood pressure, coronary artery disease, and cerebrovascular accident (27). In spite of this, no association between smoking and these diseases was presented in this study.

\section{Conclusion}

This study found that behavioral risk factors such as unhealthy eating habits, the irregular performance of physical exercise/sedentary lifestyle, overweight, and smoking were associated with some CNCDs of relevant social and economic impact in the country, such as cerebrovascular accident, cardiovascular diseases, endocrine/nutritional/metabolic diseases (excluding thyroid disorders), diabetes mellitus, systemic high blood pressure, and musculoskeletal diseases.

As a limitation to this study, we can mention that the sample was not stratified by gender or employee category. However, the results found are of great relevance because they indicate a need for these employees to adopt a healthier lifestyle.

It is also known that diseases may have a direct impact on work, reduce productivity, and increase the number of days of work leave (28). Therefore, prevention of diseases among these employees may have a positive impact on both quality of life and quality of work.

Thus, we suggest the adoption of preventative measures and control of risk behaviors by means of an institutional policy for a comprehensive care of employees' health, which may reduce the prevalence of diseases and improve health conditions and quality of life in this population.

\section{References}

1. Alwan A, Maclean DR, Riley LM, d'Espaignet ET, Mathers CD, Stevens GA, et al. Monitoring and surveillance of chronic non-communicable diseases: progress and capacity in high-burden countries. Lancet. 2010;376(9755);1861-8.

2. Schmidt MI, Duncan BB, Azevedo e Silva G, Menezes AM, Monteiro CA, Barreto SM, et al. Chronic non-communicable diseases in Brazil: burden and current challenges. Lancet. 2011;377(9781):1949-61. 
3. World Health Organization (WHO). Global status report on noncommunicable diseases 2010. Geneva: World Health Organization; 2011. 176 p.

4. Brazil. Ministério da Saúde. Guia alimentar para a população brasileira: promovendo a alimentação saudável. Brasília: Ministério da Saúde; 2008. Portuguese.

5. Lerario DDG, Gimeno SG, Franco LJ, Iunes M, Ferreira SRG. Excesso de peso e gordura abdominal para a síndrome metabólica em nipobrasileiros. Rev Saude Publica. 2002;36(1):4-11. Portuguese.

6. Pesquisa de orçamentos familiares 2008-2009 (POF). Antropometria e estado nutricional de crianças, adolescentes e adultos no Brasil. Rio de Janeiro: IBGE; 2010. Portuguese.

7. Kohl 3rd HW, Craig CL, Lambert EV, Inoue S, Alkandari JR, Leetongin G, et al. The pandemic of physical. Lancet. 2012;380:294-305.

8. Hallal PC, Andersen LB, Bull FC, Guthold R, Haskell W, Ekelund U, et al. Global physical activity levels: surveillance progress, pitfalls, and prospects. Lancet. 2012;380:247-57.

9. Pesquisa Nacional por Amostra de Domicílios (PNAD). Um panorama da saúde no Brasil: acesso e utilização dos serviços, condições de saúde e fatores de risco e proteção à saúde 2008. Rio de Janeiro: IBGE; 2010. Portuguese.

10. World Health Organization. The 10 leading causes of death by broad income group (2008). 2011 [cited 2012 Feb 16]. Available from: http://tinyurl.com/ al956p.

11. Word Health Organization. WHO Report on the global tobacco epidemic, 2008 [cited 2011 Nov 30]. Available from: http://tinyurl.com/zt2ytos.

12. Lima-Costa MF, Turci M, Macinko J. Saúde dos Adultos de Belo Horizonte. Belo Horizonte (Brazil): Núcleo de Estudos em Saúde Pública e Envelhecimento da Fundação Oswaldo Cruz e UFMG; 2012. Portuguese.

13. Organização Mundial de Saúde. Neurociência de consume e dependência a substâncias psicoativas: resumo. Genebra: Organização Mundial de Saúde; 2004.

14. Organização Mundial de Saúde. Global status report on alcohol and health. 2014 [cited 2014 Sep 5]. Available from: http://tinyurl.com/kgfb8l7.
15. Matsudo S, Araújo T, Matsudo V, Andrade D, Andrade E, Oliveira C, et al. Questionário Internacional de Atividade Física (IPAQ): estudo de validade e reprodutibilidade no Brasil. Rev Bras Ativ Fis Saude. 2001;6:5-12.

16. World Health Organization. Obesity: preventing and managing the global epidemic. Geneva: Report of a WHO Consultation on Obesity; 1995.

17. Carmo JT, Pueyo AA. A adaptação do português do Fagerström test for nicotine dependence (FTND) para avaliar a dependência e tolerância à nicotina em fumantes brasileiros. RBM Ver Bras Med. 2002;59:73-80.

18. Babor TF, Higgings-Biddle JC, Sauders JB, Monteiro MG. AUDIT: teste para identificação de problemas relacionados ao uso de álcool: roteiro para uso em atenção primária. Ribeirão Preto (Brazil): PAI-PAD; 2003. Portuguese.

19. World Health Organization. Global strategy on diet, physical activity and health. Geneva: WHO; 2004 [cited 2012 Feb 16]. Available from: http://www.who. int/dietphysi.

20. World Health Organization-Organização Panamericana de Saúde. Prevenção de doenças crônicas, um investimento vital. Geneva: WHO; 2005.

21. Ministério da Saúde, SVS. Departamento de Análise de Situação de Saúde. Vigitel Brasil 2009: vigilância de fatores de risco e proteção para doenças crônicas por inquérito telefônico. Brasília: Ministério da Saúde; 2010.

22. Oliveira RAR, Moreira OC, Andrade Neto F, Amorim W, Costa EG, Marins JCB. Prevalência de sobrepeso e obesidade em professores da Universidade Federal de Viçosa. Fisioter Mov. 2011;24:603-12.

23. Gigante DP, Moura EC, Sardinha LMV. Prevalência de excesso de peso e obesidade e fatores associados, Brasil, 2006. Rev Saude Publica. 2009;43:83-9.

24. Ministério da Saúde. Departamento de Ciência e Tecnologia, Secretaria de Ciência, Tecnologia e Insumos Estratégicos. ELSA Brasil: maior estudo epidemiológico da América Latina. Rev Saude Publica. 2009;43:1.

25. Fang MA, Frost PJ, Iida-Klein A, Hahn TJ. Effects of nicotine on cellular function in UMR 106-01 osteoblast-like cells. Bone. 1991;(12):283-6. 
26. Castillo RC, Bosse MJ, Mackenzie EJ. Impact of smoking on fracture healing and risk of complications in limbthreatening open tibia fractures. J Orthop Trauma. 2005;19:151-7.

27. Ministério da Saúde. Instituto Nacional de Câncer José Alencar Gomes da Silva. A situação do tabagismo no Brasil: dados dos inquéritos do Sistema Internacional de Vigilância, da Organização Mundial da Saúde, realizados no Brasil, entre 2002 e 2009. Rio de Janeiro: Inca; 2011.

28. Bloom DE, Cafiero ET, Jané-Llopis E, AbrahamsGessel S, Bloom LR, Fathima S, et al. The global economic burden of non-communicable diseases: report by the World Economic Forum and the Harvard School of Public Health. Geneva: World Economic Forum; 2011; [cited 2012 May 30]. Available from: http://tinyurl.com/3bdgz55.

Received in $10 / 10 / 2014$

Recebido em 10/10/2014

Approved in 10/15/2015

Aprovado em 15/10/2015 
